\title{
Actinokineospora baliensis sp. nov., Actinokineospora cibodasensis sp. nov. and Actinokineospora cianjurensis sp. nov., isolated from soil and plant litter
}

\author{
Correspondence \\ Puspita Lisdiyanti \\ puspita.lisdiyanti@lipi.go.id or \\ p_lisdiyanti@yahoo.com
}

\author{
Puspita Lisdiyanti, ${ }^{1}$ Misa Otoguro, ${ }^{2}$ Shanti Ratnakomala, ${ }^{1}$ Yulin Lestari, ${ }^{3}$ \\ Ratih D. Hastuti, ${ }^{4}$ Evi Triana, ${ }^{5}$ Ando Katsuhiko ${ }^{2}$ and Yantyati Widyastuti ${ }^{1}$ \\ ${ }^{1}$ Research Center for Biotechnology, Indonesian Institute of Sciences, Jl. Raya Bogor Km. 46, \\ Cibinong 16911, Indonesia \\ ${ }^{2}$ Department of Biotechnology, National Institute of Technology and Evaluation, 2-5-8 Kazusa \\ kamatari, Kisarazu, Chiba 292-0818, Japan \\ ${ }^{3}$ Department of Biology, Faculty of Mathematics and Natural Sciences, Bogor Agricultural \\ University, Jalan Raya Pajajaran, Bogor 16144, Indonesia \\ ${ }^{4}$ Soil Research Institute, Jl. Ir. H. Juanda 98, Bogor 16002, Indonesia \\ ${ }^{5}$ Research Center for Biology, Indonesian Institute of Sciences. Jl. Raya Bogor Km. 46, Cibinong \\ 16911, Indonesia
}

The genus Actinokineospora was proposed by Hasegawa (1988) for motile, arthrospore-bearing actinomycetes. Recently, Labeda et al. (2010) emended the description of the genus to accommodate species that have not been observed to produce motile spores, and transferred

The GenBank/EMBL/DDBJ accession numbers for the 16S rRNA gene sequence of strains ID03-0561 ${ }^{\top}$, ID03- $-0784^{\top}$ and ID03-0810 ${ }^{\top}$ are $A B 447488, A B 447489$ and $A B 473945$, respectively.

Minimum-evolution and maximum-parsimony $16 S$ rRNA gene sequencebased trees are available as supplementary material with the online version of this paper.
Amycolatopsis fastidiosa to the genus as Actinokineospora fastidiosa. At the time of writing, the genus contains eight species: Actinokineospora riparia (the type species), Actinokineospora inagensis, Actinokineospora globicatena, Actinokineospora terrae, Actinokineospora diospyrosa, Actinokineospora auranticolor, Actinokineospora enzanensis and Actinokineospora fastidiosa (Hasegawa, 1988; Tamura et al., 1995; Otoguro et al., 2001b; Labeda et al., 2010). These actinomycetes have meso-diaminopimelic acid as a cell-wall diamino acid, galactose and arabinose as diagnostic whole-cell sugars, $\mathrm{MK}-9\left(\mathrm{H}_{4}\right)$ as the predominant menaquinone, phospholipid type II, iso- $\mathrm{C}_{16: 0}$ fatty acid as 
the predominant fatty acid and DNA G $+\mathrm{C}$ contents of 69$70 \mathrm{~mol} \%$.

During the course of a study on the diversity of actinomycetes in Indonesia, six actinomycete isolates belonging to the genus Actinokineospora were found from soil and leaf-litter samples in Eka Karya Botanical Garden, Bali, and Cibodas Botanical Garden, West Java, in 2003. These isolates were isolated by the rehydration and centrifugation method for the selective isolation of motile rare actinomycetes, as described by Hayakawa et al. (2000) and Otoguro et al. (2001a). Humic acid-vitamin (HV) agar supplemented with $50 \mu \mathrm{g}$ cycloheximide $\mathrm{ml}^{-1}$ and $20 \mathrm{mg}$ nalidixic acid $\mathrm{ml}^{-1}$ was used as the isolation medium (Hayakawa \& Nonomura, 1987, 1989). Details of the isolation of the six strains are given in Table 1.

PCR amplification and sequencing of the 16S rRNA gene were performed as described previously (Tamura \& Hatano, 2001) with an ABI PRISM 3100 Genetic Analyzer (Applied Biosystems) according to the manufacturer's protocol. Phylogenetic analysis of $16 \mathrm{~S}$ rRNA gene sequences was performed using the software MEGA version 4 (Tamura et al., 2007) after multiple alignment of data by using Clustal_x (Thompson et al., 1997). Phylogenetic trees were constructed by the neighbour-joining (Saitou \& Nei, 1987), minimum-evolution (Rzhetsky \& Nei, 1993) and maximum-parsimony (Kluge \& Farris, 1969) methods. Bootstrap analysis was used to evaluate the tree topology by performing 1000 resamplings (Felsenstein, 1985) (Fig. 1). The 16S rRNA gene sequences of the Indonesian strains were continuous stretches of 1465-1477 bp. The 16S rRNA gene sequence analysis revealed that the isolates fell in the cluster of the genus Actinokineospora. Sequence similarity calculations after neighbour-joining analysis indicated that the similarity to other known type strains in the genus Actinokineospora was 97.2-99.4\%. Strains ID03-784 ${ }^{\mathrm{T}}$, ID03-808 and ID03-809 showed $100 \%$ sequence similarity, as did strains ID03-810 ${ }^{\mathrm{T}}$ and ID03-813. The closest relatives of the strains were as follows: for ID03-561 ${ }^{\mathrm{T}}$, the type strain of Actinokineospora diospyrosa ( $99.4 \%$

Table 1. Indonesian actinomycetes included in this study

All strains were isolated by the rehydration and centrifugation method (Hayakawa et al., 2000).

\begin{tabular}{|lll|}
\hline Strain & \multicolumn{1}{c|}{ Location } & Source \\
\hline Group 1 & & \\
ID03-0561 $^{\mathrm{T}}$ & Eka Karya Botanical Garden, Bali & Soil \\
Group 2 & & \\
ID03-0784 $^{\mathrm{T}}$ & Cibodas Botanical Garden, West Java & Leaf litter \\
ID03-0808 & Cibodas Botanical Garden, West Java & Leaf litter \\
ID03-0809 & Cibodas Botanical Garden, West Java & Leaf litter \\
Group 3 & & \\
ID03-0810 & Cibodas Botanical Garden, West Java & Leaf litter \\
ID03-0813 & Cibodas Botanical Garden, West Java & Leaf litter \\
\hline
\end{tabular}
for Actinokineospora terrae (99.4\%).

Cell morphology was observed on YS and HV agar by phase-contrast microscopy and scanning electron microscopy (JEOL model JSM-5400). Samples for scanning electron microscopy were prepared as described by Tamura et al. (1995). Morphological observations revealed the presence of aerial mycelium with spore chains. The spores were rod-shaped and were formed by fragmentation of the hyphae (arthrospores); the spores had smooth surfaces, as revealed by scanning electron microscopy. Cultural characteristics were recorded after 14 days of incubation at $28{ }^{\circ} \mathrm{C}$ on ISP media $2-7$, Bennett's agar, nutrient agar and water agar. The colonies were light yellow to brown. All of the isolates exhibited good growth on all of the media tested except peptone-yeast extract-iron agar (ISP medium 6 ) and water agar. None of the isolates produced a soluble brown pigment with the exception of ID03-810 ${ }^{\mathrm{T}}$ and ID03813 on Bennett's agar and tyrosine agar (ISP medium 7). Motility was observed by light microscopy using cells grown for 7-10 days at $28{ }^{\circ} \mathrm{C}$ on ISP 2 agar.

Results of chemotaxonomic analysis are given in the species descriptions. Freeze-dried cells for chemotaxonomic analyses were grown in yeast extract/glucose broth (10 g yeast extract and $10 \mathrm{~g}$ D-glucose per litre distilled water, $\mathrm{pH} 7.0$ ) on a rotary shaker at $28{ }^{\circ} \mathrm{C}$. Analyses of isomers of mesodiaminopimelic acid, whole-cell sugar patterns, menaquinones, cellular fatty acids and phospholipids were performed as described previously (Tamura et al., 1995). The chemotaxonomic properties support affiliation of the six Indonesian isolates to the family Actinosynnemataceae (Labeda \& Kroppenstedt, 2000), in which all isolates have the cell-wall type IV/A of Lechevalier \& Lechevalier (1970) with meso-diaminopimelic acid and have galactose and arabinose as the whole-cell sugars, MK-9 $\left(\mathrm{H}_{4}\right)$ as the major menaquinone and phospholipid type II of Lechevalier et al. (1981), with significant amounts of phosphatidylethanolamine and the absence of phosphatidylglycerol, phosphatidylcholine and an unidentified phosphorus-free aminolipid. The major cellular fatty acids of ID03-0561 ${ }^{\mathrm{T}}$ were iso- $\mathrm{C}_{16: 0}$ $(29.1 \%)$, iso- $\mathrm{C}_{15: 0}(17.1 \%)$ and iso- $\mathrm{C}_{17: 0}(16.7 \%)$, with small amounts of iso- $\mathrm{C}_{16: 0} 2-\mathrm{OH}$, iso- $\mathrm{C}_{15: 0} 2-\mathrm{OH}$ and anteiso- $\mathrm{C}_{17: 0}$; for the other Indonesian isolates, the major fatty acids were iso- $\mathrm{C}_{16: 0}(22.4-44.2 \%)$, iso- $\mathrm{C}_{15: 0}$ (9.8$18.8 \%)$ and iso- $\mathrm{C}_{16: 0} 2-\mathrm{OH}(10.8-14.3 \%)$.

Genomic DNA for determination of $\mathrm{G}+\mathrm{C}$ content and DNA-DNA hybridization was extracted by the method of Saito \& Miura (1963). The genomic DNA G + C content was determined by enzymic hydrolysis of DNA followed by reversed-phase HPLC as described by Tamura et al. (1994). DNA-DNA hybridization was performed by the fluorometric method in microdilution wells with photobiotin as described by Ezaki et al. (1989). Results of G+C content determination and DNA-DNA hybridization are given in 


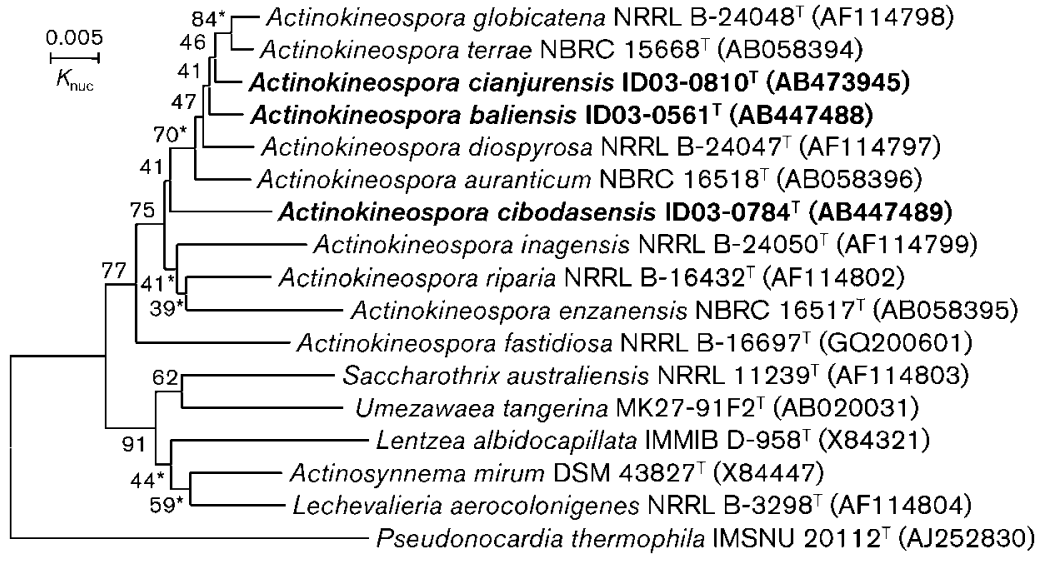

Fig. 1. 16S rRNA gene sequence dendrogram reconstructed by the neighbour-joining method using the software MEGA version 4 (Tamura et al., 2007) displaying the relatedness of the novel strains and other members of the genus Actinokineospora. The sequence of Pseudonocardia thermophila IMSNU $20112^{\top}$ was used as the outgroup. Bar, 0.005 substitutions per nucleotide position. Asterisks indicate branches of the tree that were also recovered using the minimum-evolution and maximumparsimony methods (these trees are available as Supplementary Figs S1 and S2 in IJSEM Online).
Table 2. The range of $\mathrm{G}+\mathrm{C}$ content of the isolates was $70.2-71.9 \mathrm{~mol} \%$. DNA-DNA hybridization revealed that the six Indonesian isolates were divided into three DNADNA relatedness groups. Group I contained a single isolate (ID03-0561 ${ }^{\mathrm{T}}$ ), group II contained three isolates (ID03$0784^{\mathrm{T}}$, ID03-0808 and ID03-0809) and group III contained two isolates (ID03-0810 ${ }^{\mathrm{T}}$ and ID03-0813). Group I showed low relatedness to the other Indonesian strains and the reference strains used. Strains of group II showed high relatedness to each other (98-100\%) and low relatedness to the other tested strains. The strains of group III showed 58-68\% relatedness to Actinokineospora terrae NBRC $15668^{\mathrm{T}}$ and low relatedness $(2-24 \%)$ to the other reference strains.

The results of phenotypic characterization, performed as described previously (Seino et al., 1985; Shirling \& Gottlieb, 1966; Otoguro et al., 2001b), are given in the species descriptions. The isolates used for phenotypic tests were grown in yeast extract/glucose broth medium as described for chemotaxonomic analysis and resuspended in distilled water. DNA-DNA relatedness groups I-III could be distinguished from the type strains of other species of the genus Actinokineospora by using a combination of phenotypic properties. Strain ID03-561 ${ }^{\mathrm{T}}$ in group I was positive for utilization of mannose and sucrose and negative for utilization of arabinose, galactose, fructose and rhamnose. The isolates in group II were positive for utilization of galactose, mannose, fructose, sucrose and maltose and negative for utilization of arabinose and rhamnose as sole carbon sources. The two isolates in group III were distinguished from Actinokineospora terrae by being positive for utilization of galactose and negative for utilization of arabinose and rhamnose.

It is clear from the genotypic, chemotaxonomic and phenotypic data that the six Indonesian strains represent three novel species in the genus Actinokineospora. The

Table 2. DNA base composition and DNA-DNA hybridization of Actinokineospora strains

\begin{tabular}{|c|c|c|c|c|c|c|c|c|c|c|c|}
\hline \multirow[t]{2}{*}{ Strain } & \multirow{2}{*}{$\begin{array}{c}\mathrm{G}+\mathrm{C} \text { content } \\
\quad(\mathrm{mol} \%)\end{array}$} & \multicolumn{10}{|c|}{ DNA-DNA hybridization (\%) with labelled DNA from strain: } \\
\hline & & 1 & 2 & 3 & 4 & 5 & 6 & 7 & 8 & 9 & 10 \\
\hline 2. ID03-0784 ${ }^{\mathrm{T}}$ & 71.3 & 12 & $(100)$ & $\mathrm{ND}$ & 14 & $\mathrm{ND}$ & 6 & 15 & 17 & 17 & 14 \\
\hline ID03-0808 & 71.9 & 15 & 93 & ND & 17 & ND & 11 & 23 & 35 & 32 & 9 \\
\hline ID03-0813 & 70.3 & 31 & 10 & 13 & 91 & ND & 9 & ND & ND & 65 & 25 \\
\hline 5. A. riparia $\mathrm{NBRC} 14541^{\mathrm{T}}$ & $\mathrm{ND}$ & 7 & 7 & 7 & 8 & $(100)$ & 19 & 25 & 2 & 7 & 38 \\
\hline 6. A. inagensis NBRC $15663^{\mathrm{T}}$ & ND & ND & 20 & ND & ND & ND & $(100)$ & 27 & 30 & 25 & 30 \\
\hline 7. A. globicatena NBRC $15664^{\mathrm{T}}$ & $\mathrm{ND}$ & 26 & 24 & $\mathrm{ND}$ & $\mathrm{ND}$ & 28 & 1 & $(100)$ & 13 & 26 & 32 \\
\hline 8. A. diospyrosa NBRC $15665^{\mathrm{T}}$ & ND & 20 & 7 & 9 & 12 & 16 & 9 & 20 & $(100)$ & 24 & 39 \\
\hline 9. A. terrae NBRC $15668^{\mathrm{T}}$ & $\mathrm{ND}$ & 29 & 15 & 19 & 68 & 20 & 4 & 30 & 10 & $(100)$ & 20 \\
\hline
\end{tabular}

ND, Not determined. 
names Actinokineospora baliensis sp. nov., Actinokineospora cibodasensis sp. nov. and Actinokineospora cianjurensis sp. nov. are proposed for DNA-DNA hybridization groups I-III.

\section{Description of Actinokineospora baliensis sp. nov.}

Actinokineospora baliensis (ba.li.en'sis. N.L. fem. adj. baliensis pertaining to Bali, Indonesia, from where the type strain was isolated).

Morphological, chemotaxonomic and general characteristics are as given for the genus by Hasegawa (1988) and Labeda et al. (2010). Vegetative mycelium is pale yellow. When formed, aerial mycelium is white. Aerial mycelium produces rod-shaped arthrospores (diameter 1.5-2.0 $\mu \mathrm{m}$ ) with smooth surfaces that exhibit motility when suspended in sterile distilled water. Good growth at $25-28{ }^{\circ} \mathrm{C}$. Grows well on ISP media 2, 3, 5 and 7, Bennett's agar and nutrient agar; does not grow on ISP media 4 or 6 or water agar. Grows in the presence of $1 \% \mathrm{NaCl}$, but not in the presence of 3, 5 or $7 \% \mathrm{NaCl}$. Reduces nitrate to nitrite. Hydrolyses aesculin, urea and gelatin. Utilizes glucose, trehalose, mannose, sucrose and maltose as carbon sources, but not arabinose, galactose, rhamnose, lactose, raffinose, sorbitol, xylose, cellobiose, melibiose, meso-erythritol, inositol, mannitol, ribitol, dulcitol or xylitol. Degrades xanthine and elastin but not testosterone, gelatin or calcium malate. Peptonizes milk. iso- $\mathrm{C}_{16: 0}$, iso- $\mathrm{C}_{15: 0}$ and iso- $\mathrm{C}_{17: 0}$ are the major cellular fatty acids. The $\mathrm{G}+\mathrm{C}$ content of the DNA of the type strain is $71.4 \mathrm{~mol} \%$.

The type strain, ID03-0561 ${ }^{\mathrm{T}}$ (=BTCC B-554 ${ }^{\mathrm{T}}=\mathrm{NBRC}$ $104211^{\mathrm{T}}$ ), was isolated from soil under a Manglietia glauca tree in Eka Karya Botanical Garden, Bali, Indonesia.

\section{Description of Actinokineospora cibodasensis sp. nov.}

Actinokineospora cibodasensis (ci.bo.da.sen'sis. N.L. fem. adj. cibodasensis pertaining to Cibodas, West Java, Indonesia, from where the first strains were isolated).

Morphological, chemotaxonomic and general characteristics are as given for the genus by Hasegawa (1988) and Labeda et al. (2010). Vegetative mycelium is yellow to tan. When formed, aerial mycelium is white. Aerial mycelium produces rod-shaped arthrospores (diameter 1.5-1.8 $\mu \mathrm{m}$ ) which have smooth surfaces and exhibit motility when suspended in sterile distilled water. Good growth at 25$28{ }^{\circ} \mathrm{C}$. Grows well on ISP media 2, 3, 4, 5 and 7, Bennett's agar and nutrient agar; does not grow on ISP medium 6 or water agar. Grows in the presence of $1 \% \mathrm{NaCl}$, but not 3, 5 or $7 \% \mathrm{NaCl}$. Reduces nitrate to nitrite. Hydrolyses aesculin, urea and gelatin. Utilizes glucose, trehalose, galactose, mannose, fructose, sucrose and maltose, but not arabinose, rhamnose, lactose, raffinose, sorbitol, xylose, cellobiose, melibiose, meso-erythritol, inositol, mannitol, ribitol, dulcitol or xylitol. Degrades xanthine, elastin and testosterone, but not gelatin or calcium malate. Does not peptonize milk. iso- $\mathrm{C}_{16: 0}$, iso- $\mathrm{C}_{15: 0}$ and iso- $\mathrm{C}_{16: 0} 2-\mathrm{OH}$ are the major cellular fatty acids. The $\mathrm{G}+\mathrm{C}$ content of the DNA of the type strain is $71.3 \mathrm{~mol} \%$.

The type strain, ID03- $0748^{\mathrm{T}}$ (=BTCC B-555 ${ }^{\mathrm{T}}=\mathrm{NBRC}$ $\left.104212^{\mathrm{T}}\right)$, was isolated from a leaf-litter sample from Cibodas Botanical Garden, West Java, Indonesia. Strains ID03-0808 and ID03-0809, from the same source, are also representatives of the species.

\section{Description of Actinokineospora cianjurensis sp. nov.}

Actinokineospora cianjurensis (ci.an.jur.en'sis. N.L. fem. adj. cianjurensis pertaining to Cianjur, West Java, Indonesia, from where the first strains were isolated).

Morphological, chemotaxonomic and general characteristics are as given for the genus by Hasegawa (1988) and Labeda et al. (2010). Vegetative mycelium is yellow to brown. When formed, aerial mycelium is white. Aerial mycelium produces rod-shaped arthrospores (diameter 1.5-2.0 $\mu \mathrm{m}$ ) which have smooth surfaces and exhibit motility when suspended in sterile distilled water. Good growth at $25-28{ }^{\circ} \mathrm{C}$. Grows well on ISP media 2, 3, 4, 5 and 7 , Bennett's agar and nutrient agar, but not on ISP medium 6 or water agar. Grows in the presence of $1 \% \mathrm{NaCl}$, but not 3,5 or $7 \% \mathrm{NaCl}$. Reduces nitrate to nitrite. Hydrolyses aesculin, urea and gelatin. Utilizes glucose, trehalose, galactose, mannose, fructose, sucrose and maltose, but not arabinose, rhamnose, lactose, raffinose, sorbitol, xylose, cellobiose, melibiose, meso-erythritol, inositol, mannitol, ribitol, dulcitol or xylitol. Degrades xanthine, elastin and testosterone, but not gelatin or calcium malate. Peptonizes milk. iso- $\mathrm{C}_{16: 0}$, iso- $\mathrm{C}_{15: 0}$ and iso- $\mathrm{C}_{16: 0} 2-\mathrm{OH}$ are the major cellular fatty acids. The $\mathrm{G}+\mathrm{C}$ content of the DNA of the type strain is $70.2 \mathrm{~mol} \%$.

The type strain, ID03- $0810^{\mathrm{T}}\left(=\mathrm{BTCC} B-558^{\mathrm{T}}=\mathrm{NBRC}\right.$ $\left.105526^{\mathrm{T}}\right)$, was isolated from a leaf-litter sample from Cibodas Botanical Garden, West Java, Indonesia. Strain ID03-0813, isolated from the same source, is a second representative of the species.

\section{Acknowledgements}

We are grateful to Hideki Yamamura and Yayoi Sakiyama for providing technical assistance during chemotaxonomic studies. This work was conducted collaboratively between the Indonesian Institute of Sciences (LIPI), representing the Government Research Centers (GRC) of the Republic of Indonesia, and the National Institute of Technology and Evaluation (NITE), Japan.

\section{References}

Ezaki, T., Hashimoto, Y. \& Yabuuchi, E. (1989). Fluorometric deoxyribonucleic acid-deoxyribonucleic acid hybridization in microdilution wells as an alternative to membrane filter hybridization in 
which radioisotopes are used to determine genetic relatedness among bacterial strains. Int J Syst Bacteriol 39, 224-229.

Felsenstein, J. (1985). Confidence limits on phylogenies: an approach using the bootstrap. Evolution 39, 783-791.

Hasegawa, T. (1988). Actinokineospora: a new genus of the Actinomycetales. Actinomycetologica 2, 31-45.

Hayakawa, M. \& Nonomura, H. (1987). Humic acid-vitamin agar, a new medium for selective isolation of soil actinomycetes. J Ferment Technol 65, 501-509.

Hayakawa, M. \& Nonomura, H. (1989). A new method for the intensive isolation of actinomycetes from soil. Actinomycetologica 3, 95-104.

Hayakawa, M., Otoguro, M., Takeuchi, T., Yamazaki, T. \& limura, Y. (2000). Application of a method incorporating differential centrifugation for selective isolation of motile actinomycetes in soil and plant litter. Antonie van Leeuwenhoek 78, 171-185.

Kluge, A. G. \& Farris, J. S. (1969). Quantitative phyletics and the evolution of anurans. Syst Zool 18, 1-32.

Labeda, D. P. \& Kroppenstedt, R. M. (2000). Phylogenetic analysis of Saccharothrix and related taxa: proposal for Actinosynnemataceae fam. nov. Int J Syst Evol Microbiol 50, 331-336.

Labeda, D. P., Price, N. P., Tan, G. Y. A., Goodfellow, M. \& Klenk, H.-P. (2010). Emended description of the genus Actinokineospora Hasegawa 1988 and transfer of Amycolatopsis fastidiosa Henssen et al. 1987 as Actinokineospora fastidiosa comb. nov. Int J Syst Evol Microbiol 60, 1444-1449.

Lechevalier, M. P. \& Lechevalier, H. A. (1970). Chemical composition as a criterion in the classification of aerobic actinomycetes. Int J Syst Bacteriol 20, 435-443.

Lechevalier, M. P., Stern, A. E. \& Lechevalier, H. A. (1981). Phospholipids in the taxonomy of actinomycetes. In Actinomycetes. Proceedings of the Fourth International Symposium on Actinomycete Biology, pp. 111-116. Edited by K. P. Schaal \& G. Pulverer. New York: Gustav Fischer.

Otoguro, M., Hayakawa, M., Yamazaki, T. \& limura, Y. (2001a). An integrated method for the enrichment and selective isolation of Actinokineospora spp. in soil and plant litter. J Appl Microbiol 91, 118-130.

Otoguro, M., Hayakawa, M., Yamazaki, T., Tamura, T., Hatano, K. \& limura, Y. (2001b). Numerical phenetic and phylogenetic analysis of
Actinokineospora isolates, with a description of Actinokineospora auranticolor sp. nov. and Actinokineospora enzaensis sp. nov. Actinomycetologica 15, 30-39.

Rzhetsky, A. \& Nei, M. (1993). Theoretical foundation of the minimum-evolution method of phylogenetic inference. Mol Biol Evol 10, 1073-1095.

Saito, H. \& Miura, K. (1963). Preparation of transforming deoxyribonucleic acid by phenol treatment. Biochim Biophys Acta 72, 612-629.

Saitou, N. \& Nei, M. (1987). The neighbor-joining method: a new method for reconstructing phylogenetic trees. Mol Biol Evol 4, 406425.

Seino, A., Arai, M., Enokida, R., Okazaki, T. \& Furuichi, A. (1985). Identification Manual of Actinomycetes. Tokyo: The Society for Actinomycetes.

Shirling, E. B. \& Gottlieb, D. (1966). Methods for characterization of Streptomyces species. Int J Syst Bacteriol 16, 313-340.

Tamura, T. \& Hatano, K. (2001). Phylogenetic analysis of the genus Actinoplanes and transfer of Actinoplanes minutisporangius Ruan et al. 1986 and 'Actinoplanes aurantiacus' to Cryptosporangium minutisporangium comb. nov. and Cryptosporangium aurantiacum sp. nov. Int J Syst Evol Microbiol 51, 2119-2125.

Tamura, T., Nakagaito, Y., Nishii, T., Hasegawa, T., Stackebrandt, E. \& Yokota, A. (1994). A new genus of the order Actinomycetales, Couchioplanes gen. nov., with descriptions of Couchioplanes caeruleus (Horan and Brodsky 1986) comb. nov. and Couchioplanes caeruleus subsp. azureus subsp. nov. Int J Syst Bacteriol 44, 193-203.

Tamura, T., Hayakawa, M., Nonomura, H., Yokota, A. \& Hatano, K. (1995). Four new species of the genus Actinokineospora: Actinokineospora inagensis sp. nov., Actinokineospora globicatena sp. nov., Actinokineospora terrae sp. nov. and Actinokineospora diospyrosa sp. nov. Int J Syst Bacteriol 45, 371-378.

Tamura, K., Dudley, J., Nei, M. \& Kumar, S. (2007). MEGA4: molecular evolutionary genetics analysis (MEGA) software version 4.0. Mol Biol Evol 24, 1596-1599.

Thompson, J. D., Gibson, T. J., Plewniak, F., Jeanmougin, F. \& Higgins, D. G. (1997). The CLUSTAL_X windows interface: flexible strategies for multiple sequence alignment aided by quality analysis tools. Nucleic Acids Res 25, 4876-4882. 